\title{
EXPERIMENTAL RESEARCHES OF PARAMETERS TECHNOLOGICAL PROCESS OF THE IMPROVED BEETS TOPS PURIFIER
}

\author{
Anna Tson; Viktor Baranovskyi; Oleg Lyashuk; Taras Dovbush
}

Ternopil Ivan Puluj National Technical University, Ternopil, Ukraine

\begin{abstract}
Summary. In this article, the problem of the need to improve existing and development of essentially new beet-harvesting machines is investigated since the existing ones do not fully satisfy the agronomic requirements for the process of harvesting roots. The results of experimental studies of the improved beet-harvesting machine are presented. The technological efficiency of application of the improved design of the cutter of the remnants of the wedge was determined by conducting field comparative studies of the two types of denominators, which distinguished themselves from the constructive execution of the comb copier and knife. The surface of the reviews and their two-dimensional sections of the damage to the root crops and the number of cut root crops from the soil were constructed, depending on the speed of the root-crop modulus and the height of the root crops.
\end{abstract}

Key words: tops, root crops, cutting, two-factor experiment, knife.

https://doi.org/10.33108/visnyk_tntu2018.04.060

Reserived 02.01.2019

Statement of the problem. Stable development of the agro-industrial complex is impossible without the development and implementation of fundamentally new and progressive methods enabling to design efficient technical means and mechanisms for agriculrural crops harvesting. The development of new and improvement of existing constructions of root crop harvesting machines and aggregates is caused by the need for production of beet-harvesting machines by domestic mechanical engineering at the level of the best world analogues as Ukraine belongs to the main world beet-growing countries [1].

Analysis of the available investigations and publications. The results of theoretical and experimental investigations of the operation of top gathering module and its mechanisms requiring more detailed description and analysis based on data obtained during experimental tests are given in papers $[2,3,4]$.

The objective of the paper is to carry out analysis of experimentally obtained data on the work of the improved top gathering machine in accordance with the research program and verify the relevance of empirical dependencies describing the cutter knife along the root head [5].

Statement of the task. In order to determine the technological efficiency of the application of the top cutter improved design on the root heads installed on the top gathering module, field comparative experimental investigations of two types of cutters which differ by constructive performance of collar feeler and knife were carried out.

Results of the investigation. The program for carrying out experimental investigations of the improved top remains cutter provided the determination of the root crop damage $P_{k e}$ and the number of cut root crops from the soil $B_{k e}$ by the operating elements of the root crop harvestine module (in percentage of the root crop total mass) for two types of constructive performance of the cutter [5].

Technical characteristics of the field installation of the top gathering module are given in Table 1. 
Table 1

Technical characteristics of the top gathering module

\begin{tabular}{|c|c|}
\hline Indexes & Indicators Value \\
\hline Operating width, $\mathrm{m}$ & 2,7 \\
\hline Number of rows, pcs. & 6 \\
\hline Diameter of top cutter rotor, $\mathrm{m}$ & 0,5 \\
\hline Rotor rotating velocity, rev./min. & 500 \\
\hline Screw conveyor diameter, $\mathrm{m}$ & $0,2 \ldots 0,3$ \\
\hline Screw conveyor rotational frequency, rev./min. & $20 \ldots 150$ \\
\hline Screw conveyor pitch, $\mathrm{m}$ & 0,25 \\
\hline
\end{tabular}

The sequence of the first and subsequent experiments was established in accordance with the numbered order of the randomized plan matrix of the planned multifactorial experiment.

At the same time, the investigations were carried out on the basis of the implementation of two-factor experiment at three levels of factors variation or factorial experiment $3^{2}$ type experiment the scheme of which is shown in Fig. 1.

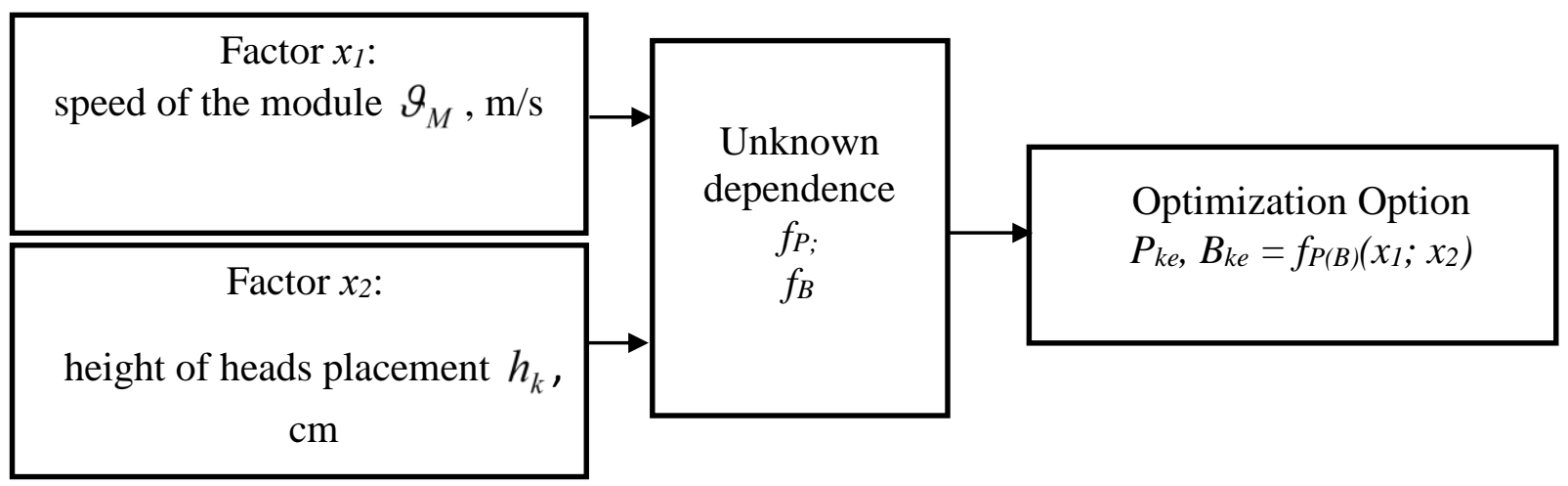

Figure 1. Scheme of the planned factor experiment $3^{2}$ type in Table. 2

Characteristics of the determined factors and the value of their variation levels are given

Table 2

Results of coding the factors and their variation level during experimental investigations

\begin{tabular}{|c|c|c|c|c|c|c|}
\hline \multirow[b]{2}{*}{ Factors } & \multicolumn{2}{|c|}{ Symsols } & \multirow{2}{*}{$\begin{array}{l}\text { Variation } \\
\text { interval }\end{array}$} & \multirow{2}{*}{\multicolumn{3}{|c|}{$\begin{array}{l}\text { Variation levels, } \\
\text { natural/coded }\end{array}$}} \\
\hline & Natural & Coded & & & & \\
\hline Module motion speed, $\mathrm{m} / \mathrm{s}$ & $\vartheta_{M}$ & $x_{1}$ & 0,3 & $1,6 /-1$ & $1,9 / 0$ & $2,2 /+1$ \\
\hline Head location height, $\mathrm{cm}$ & $h_{k}$ & $x_{2}$ & 3,0 & $5,0 /-1$ & $8,0 / 0$ & $11,0 /+1$ \\
\hline
\end{tabular}


On the basis of the implementation of the selected experimental plan, according to the given method, the dependences characterizing the change in root crop damage $P_{k e}$ and the number of cut root crops $B_{k e}$ from the soil by the operating elements of the top gathering module on the simultaneous change of the two factors - the speed of the top gathering module $\vartheta_{M}$ and the height of the root crops location in relation to the soil surface $h_{k}$ in the form of the function $P_{k e} ; B_{k e}=f_{P(B)}\left(\vartheta_{M}, h_{k}\right)$.

The response function (optimization parameter), i.e., empirical dependence or regression equation, characterizing the change in root crop damage $P_{k e}$ and the number of cut root crops $B_{k e}$ from the soil by the operating elements of the top gathering module from the simultaneous change of two operating factors - the speed of the top gathering module $\vartheta_{M}$ and the height of the root crops location relatively to the soil surface $h_{k}$, defined experimentally, were assumed as mathematical model of complete polynomial of the second degree

$$
P_{i k e} ; B_{i k e}=b_{o}+b_{1} x_{1}+b_{2} x_{2}+b_{12} x_{12}+b_{11} x_{1}^{2}+b_{22} x_{2}^{2},
$$

where $b_{o}, b_{1}, b_{2}, b_{12}, b_{11}, b_{22}$ - are the corresponding coefficients for the coded factor values of the regression equation; $x_{1}, x_{2}-$ are coded factors.

After the received experimental data array processing carried out in accordance with the well-known methodthe unknown coefficients of the regression equation were determined [6].

\section{Table 3}

The values of the regression equation coefficients during the investigation of root crop damage $P_{k e}$ the number of cut root crops $B_{k e}$ from the soil by the operating elements of the top gathering module

\begin{tabular}{|c|c|c|c|c|c|c|}
\hline \multirow{2}{*}{ Symbols } & \multicolumn{7}{|c|}{ Coefficient values } \\
\cline { 2 - 7 } & $b_{0}$ & $b_{1}$ & $b_{2}$ & $b_{12}$ & $b_{11}$ & $b_{22}$ \\
\hline$P_{1 k e}=f_{P}\left(\vartheta_{M}, h_{k}\right)$ & $-0,75$ & 3,33 & $-1,74$ & 0,54 & $-1,04$ & 0,12 \\
\hline$P_{2 k e}=f_{P}\left(\vartheta_{M}, h_{k}\right)$ & 6,6 & $-3,96$ & $-1,68$ & 0,42 & 0,73 & 0,11 \\
\hline$B_{1 k e}=f_{B}\left(\vartheta_{M}, h_{k}\right)$ & 16,11 & $-12,5$ & $-2,87$ & 0,42 & 4,58 & 0,35 \\
\hline$B_{2 k e}=f_{B}\left(\vartheta_{M}, h_{k}\right)$ & $-5,66$ & 5,08 & $-1,87$ & 1,08 & $-0,42$ & 0,1 \\
\hline
\end{tabular}

The verification of the selected model adequacy presented in the form of the functional $\left.P_{k e} ; B_{k e}=f_{P(B)}\left(\vartheta_{M}, h_{k}\right)\right)$, i. e., the relevance of the empirical distribution of the random variables of the regression equations to the real experimental process was carried out according to Fisher's criterion [7] which tabular significance was denoted as $F_{T}\left(0,05 ; f_{a g} ; f_{u}\right)$, where 0.05 means $5 \%$ significance level (equal to $1-\alpha$, where $\alpha$ is the confidence probability).

According to the calculations results the condition of adequacy is true, i.e. the chosen mathematical model adequately describes the received experimental data array, or is adequate to the investigated process. 
The statistical significance of the coefficients $b_{i}, b_{i j}, b_{i i}$ of the regression equations was carried out according to the Student's t - criterion [7] at the same time it was determined that all coefficients of the regression equation are significant.

Regression equations in natural quantities characterizing the change in the root crop damage $P_{k e}$ and the number of cut root crops from the soil $B_{k e}$ by the operating elements of the top gathering module in the form of functional dependence $P_{1 k e}=f_{P}\left(\vartheta_{M}, h_{k}\right)$, $P_{2 k e}=f_{P}\left(\vartheta_{M}, h_{k}\right), B_{1 k e}=f_{B}\left(\vartheta_{M}, h_{k}\right)$ and $B_{2 k e}=f_{B}\left(\vartheta_{M}, h_{k}\right)$ within the limits of two operating factors change (speed the top gathering module movement $1,6 \leq 2_{M} \leq 2,4 \mathrm{~m} / \mathrm{s}$, the height of the root crops location relatively to the soil surface $3,0 \leq h_{k} \leq 9,0 \mathrm{~cm}$ ), are as follows:

- the number of damaged root crops $P_{1 k e}$ and $P_{2 k e}$ from the total mass of roots of one sample:

$$
\left.\begin{array}{l}
P_{1 k e}=-0,75+3,33 \vartheta_{M}-1,74 h_{k}+0,54 \vartheta_{M} h_{k}-1,04 \vartheta_{M}^{2}+0,12 h_{k}^{2} ; \\
P_{2 k e}=6,6-3,96 \vartheta_{M}-1,68 h_{k}+0,42 \vartheta_{M} h_{k}+0,73 \vartheta_{M}^{2}+0,11 h_{k}^{2}
\end{array}\right\} ;
$$

where $P_{1 k e}, P_{2 k e}$ - relatively, root crop damage by the serial cutter and the cutter, which knife isproduced as spring-loaded, and the feeler is installed on the shock absorber, $\%$.

- the number of cut root crops from the soil $P_{1 k e}$ and $P_{2 k e}$ from the total mass of roots of one sample:

$$
\left.\begin{array}{l}
B_{1 k e}=16,11-12,5 \vartheta_{M}-2,87 h_{k}+0,42 \vartheta_{M} h_{k}+4,58 \vartheta_{M}^{2}+0,35 h_{k}^{2} ; \\
B_{2 k e}=-5,66+5,08 \vartheta_{M}-1,87 h_{k}+1,08 \vartheta_{M} h_{k}-0,42 \vartheta_{M}^{2}+0,1 h_{k}^{2}
\end{array}\right\} ;
$$

where $B_{1 k e}, B_{2 k e}$ - relatively, the number of cut root crops from the soil by the serial cutter and the cutter, which knife is produced as spring-loaded, and the feeler is installed on the shock absorber, \%.

According to the regression equations (2) and (3), the response surface and its twodimensional cross-section (Fig. 2 and Fig. 3) characterizing the functional change of the root crop damage $P_{k e}$ and the number of cut root crops from the soil $B_{k e}$ by the operating elements of the top gathering module for two types of constructive performance of the cutter of the top remains from the root heads depending on the speed of the top gathering module $\vartheta_{M}$ movement and the height of the root crops location relatively to the soil surface $h_{k}$ within the limits of their change: $1,6 \leq \vartheta_{M} \leq 2,2 \mathrm{~m} / \mathrm{s} ; 3,0 \leq h_{k} \leq 9,0 \mathrm{~cm}$ are constructed. 

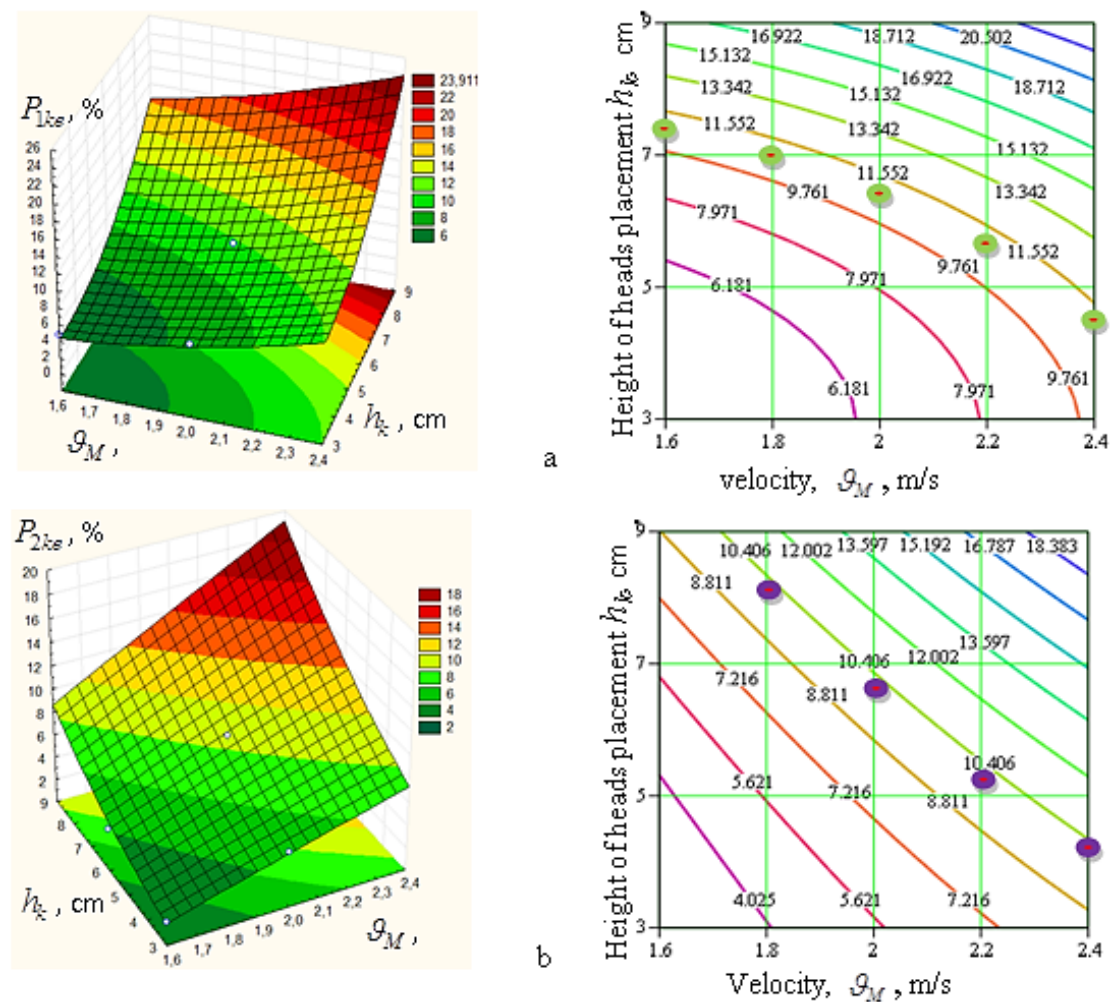

Figure 2. Response surface and its two-dimensional cross-section of root damage as function:

$$
\mathrm{a}-P_{1 k e}=f_{P}\left(\vartheta_{M}, h_{k}\right) ; \mathrm{b}-P_{2 k e}=f_{P}\left(\vartheta_{M}, h_{k}\right)
$$
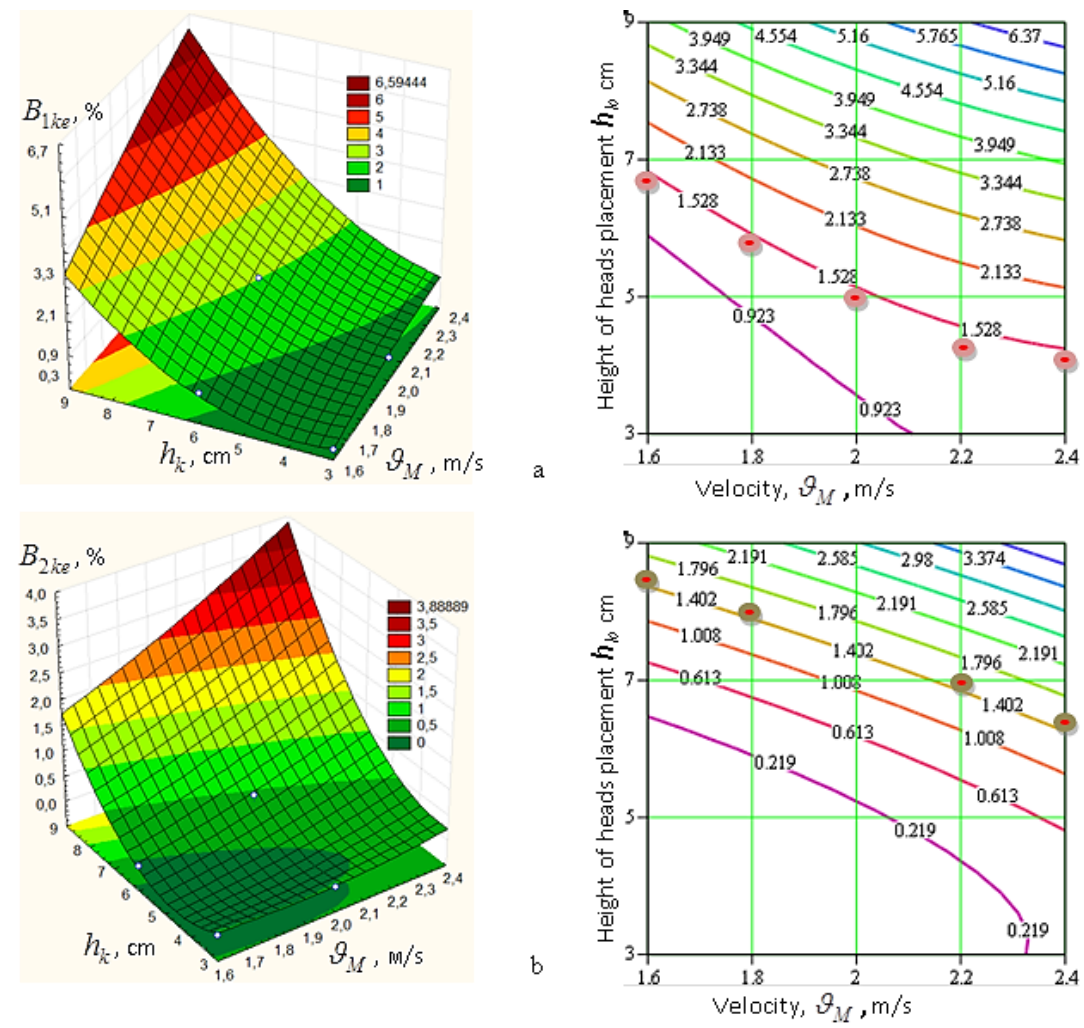

Figure 3. Response surface and its two-dimensional cross-section of the number of cut root crops from the soil as function: $\mathrm{a}-B_{1 k e}=f_{B}\left(\vartheta_{M}, h_{k}\right) ; \mathrm{b}-B_{2 k e}=f_{B}\left(\vartheta_{M}, h_{k}\right)$ 
On the basis of the carried out analysis of the regression equations (2) and response surfaces constructed in accordance with them and two-dimensional cross-sections of the response surfaces (Fig. 2), it was determined that the nature of the change in the root crop damage $P_{1 k e}, P_{2 k e}$ for two types of constructive performance of the root crop cutter of top gathering module, is similar or the same - with rise of top gathering module $\vartheta_{M}$ and the height of the root crops location $h_{k}$ relatively to the soil surface level, the root crop damage also increases.

In this case, the greatest root crop damage is observed in the first design of the root heads cutter, which is produced according to the "passive feeler-passive knife» type or serial cutter, which values are in the range $P_{1 k e}=6,0 \ldots 24,0 \%$ (Fig. 2a).

Relatively, the minimum root crop damages, which values are in the range of $P_{2 k e}=2 \ldots 18 \%$ (Fig. $3 \mathrm{~b}$ ), are obtained for the cutter with spring-loaded produced knife, the copier installed on the shock absorber and made as an elastic gasket.

A significant reduction in the root crop damagem for the second type of constructive performance of the root crops cutter $P_{2 k e}$ relatively to the index $P_{1 k e}$ is achieved by substitution the rigid process of top sterms «cutting» for the cutting process by sliding of the cutting edge of the spring-loaded knife and partial compensation of the horizontal component of the root crops contact force by the shock absorber installed on the platelike feeler support.

The dominant factor affecting the optimization parameter or root crop damage is the height of the root crops location relatively to the soil level $h_{k}$ (Fig. 3).

Within the limits of increasing the height of the root crops location over the soil surface level from 3 to $9 \mathrm{~cm}$, the root crop damage by the operating elements of two types, the cutting knife and root crops cutting feeler of the cutter of root crops performance increases in average by $2.5 \ldots 3$ times.

On the basis of the carried out analysis of the regression equations (3) and the responses surfaces constructed according to them and their two-dimensional cross-sections (Fig. 3), it was determined that the nature of the change in the number of cut root crops from the soil $B_{1 k e}, B_{2 k e}$ for two types of constructive performance of the root heads cutter heads is the same - with the increase of the top gathering module speed $\vartheta_{M}$ and the height of the root crops location $h_{k}$ relatively to the soil surface, the values $B_{1 k e}, B_{2 k e}$ increase (Fig. 3).

At the same time, the largest number of cut root crops from the soil is observed in the serial cutter, which the values are in the range of $B_{1 k e}=1,0 \ldots 6,5 \%$.

Accordingly, the minimum values of the number of cut root crops from the soil $B_{2 k e}=$ $0,5 \ldots 3,9 \%$ are obtained for the cutter with spring-loaded produced knife and the copier rigidly installed on the shock absorber produced in the form of the elastic gasket.

A significant reduction in the number of cut root crops from the soil $B_{2 k e}$ for the second type of construction cutter of root crops relatively to the index $B_{1 k e}$ is achieved by substituting the rigid process of top sterms «cutting» for the cutting process by sliding of the cutting edge of the spring-loaded knife and partial compensation of the horizontal component of the root crops contact force by the shock absorber.

The dominant factor that affects the optimization parameter or the number of cut root crops from the soil is the height of the root crops location of relatively to the soil level $h_{k}$. 
Within the limits of increasing the height of the root crops location at soil surface level from 3 to $9 \mathrm{~cm}$, the number of cut root crops from the soil by the operating elements of two types the performance of cutting knife and the cutting feeler of top gathering module are increased in average by 3 ... 4 times, Fig. 3.

Conclusions. Taking into account the above mentioned, we can state that the offered mathematical model of the process of removing the remains from the root crops head reasonably describes the experimental data array obtained and corresponds to the investigated process. It has been established that a significant reduction in the root crop damage for the second type of constructive performance of the root cropper cutter is achieved by substituting the rigid process of top sterms «cutting» for the cutting process by sliding of the cutting edge of the spring-loaded knife and partial compensation of the horizontal component of the root crops contact force by the shock absorber installed on the platelike feeler support.

\section{References}

1. Anna Tson, Substantiation of capacity of screw conveyer of haulm-cutting module, Anna Tson, Tymofii Rybak, Mykola Stashkiv, Taras Shchur Ternopil Ivan Pul'uj National Technical University, MOTROL. Commission of Motorization and Energetics in Agriculture. 2018. Vol. 20. No. 1. 83 - 89.

2. Rybak T., Tson A., Stashkiv M., Tson O. Analytical and applied model of the process of the cut vegetable components feeding to the screw conveyor of the top gathering module. Scientific Journal of TNTU (Tern.), 2018 vol. 90, no 2, pp. 105 - 114. https://doi.org/10.33108/visnyk_tntu2018.02.105

3. Oleg Lyashuk. Torsional oscillations of an auger multifunctional conveyor's screw working body with consideration of the dynamics of a processed medium continuous flow / Oleg Lyashuk, Maria Sokil, Yuriy Vovk, Anna Tson, Andrii Gupka, Oleksandr Marunych // Ukrainian Food Journal. 2018. Volume 7. Issue 3. Pp. 499 - 510. https://doi.org/10.24263/2304-974X-2018-7-3-14

4. Anna Tson. Feasibility study of an auger conveyor performance of the haulm removing module / Anna Tson, Nadia Khomuk, Taras Dovbush, Oleh Tson // Scientific Journal of TNTU. Tern.: TNTU, 2018. Vol 91. No 3. Pp. 101 - 106. https://doi.org/10.33108/visnyk_tntu2018.03.101

5. Tson H.B. Prohrama doslidzhennia robochykh orhaniv hychkozbyralnoho modulia / Zbirnyk tez dopovidei VII Mizhnarodnoi naukovo-tekhnichnoi konferentsii molodykh uchenykh ta studentiv «Aktualni zadachi suchasnykh tekhnolohii» - Ternopil, TNTU im. I. Puliuia, 2018. - p. 215. [In Ukrainian].

6. Zavalyshyn F.S., Mantsev N.H. Metodu yssledovanyi po mekhanyzatsyy selskokhoziaistvennoho proyzvodstva. M.: Kolos, 1982. 228 p. [In Russian].

7. Shenk Kh. Teoryia ynzhenernoho эksperymenta. M.:Myr, 1972. 374 p. [In Russian].

\section{Список використаної літератури}

1. Anna Tson, Substantiation of capacity of screw conveyer of haulm-cutting module [Text] / Anna Tson, Tymofii Rybak, Mykola Stashkiv, Taras Shchur Ternopil Ivan Pul'uj National Technical University, MOTROL. Commission of Motorization and Energetics in Agriculture. - 2018. - Vol. 20. No. 1. 83 - 89.

2. Rybak T., Tson A., Stashkiv M., Tson O. Analytical and applied model of the process of the cut vegetable components feeding to the screw conveyor of the top gathering module [Text] / Scientific Journal of TNTU (Tern.). - 2018. - Vol. 90, no 2, pp. 105 - 114. Режим доступа: https://doi.org/ 10.33108/visnyk_tntu2018.02.105

3. Oleg Lyashuk. Torsional oscillations of an auger multifunctional conveyor's screw working body with consideration of the dynamics of a processed medium continuous flow [Text] / Oleg Lyashuk, Maria Sokil, Yuriy Vovk, Anna Tson, Andrii Gupka, Oleksandr Marunych // Ukrainian Food Journal. - 2018. Volume 7. - Issue 3. - Pp. 499 - 510. Режим доступа: https://doi.org/10.24263/2304-974X-2018-7-3-14

4. Anna Tson. Feasibility study of an auger conveyor performance of the haulm removing module [Text] / Anna Tson, Nadia Khomuk, Taras Dovbush, Oleh Tson // Scientific Journal of TNTU. - Tern.: TNTU, 2018. - Vol. 91. - No 3. - P. 101 - 106. https://doi.org/10.33108/visnyk_tntu2018.03.101

5. Цьонь, Г.Б. Програма дослідження робочих органів гичкозбирального модуля [Текст] / Збірник тез доповідей VII Міжнародної науково-технічної конференції молодих учених та студентів «Актуальні задачі сучасних технологій». - Тернопіль, ТНТУ ім. І. Пулюя, 2018. - С. 215. 
6. Завалишин, Ф.С., Методы исследований по механизации сельскохозяйственного производства [Текст] / Ф.С. Завалишин, Н.Г. Манцев. - М.: Колос, 1982. - 228 с.

7. Шенк, Х. Теория инженерного эксперимента [Текст] / Х. Шенк. - М.: Мир, 1972. - 374 с.

\title{
УДК 631.31
}

\section{ЕКСПЕРИМЕНТАЛЬНІ ДОСЛІДЖЕННЯ ПАРАМЕТРІВ ТЕХНОЛОГІЧНОГО ПРОЦЕСУ РОБОТИ ВДОСКОНАЛЕНОГО ОБРІЗНИКА ЗАЛИШКІВ ГИЧКИ}

\section{Ганна Цьонь; Віктор Барановський; Олег Ляшук; Тарас Довбуш}

\author{
Тернопільський національний технічний університет імені Івана Пулюя, \\ Тернопіль, Україна
}

\begin{abstract}
Резюме. Досліджено проблему, що полягає в необхідності вдосконалення існуючих та розробленні принципово нових гичкозбиральних механізмів і машин, оскільки наявні не повною мірою задовольняють агротехнічні вимоги до процесу збирання коренеплодів. Наведено результати експериментальних досліджень роботи вдосконаленого обрізника залишків гички гичкозбирального модуля. Визначено технологічну ефективність застосування вдосконаленої конструкції обрізника залишків гички шияхом проведення польових порівняльних досліджень двох типів обрізувачів, які відрізнялися між собою конструктивним виконанням гребінчастого копіра та ножа. Відповідно до програми проведення експериментальних досліджень визначено пошкодження коренеплодів та кількість вибитих коренеплодів з трунту робочими органами гичкозбирального модуля (у відсотках відносно загальної маси коренеплодів) для двох типів конструктивного виконання обрізника. Дослідження проведено на основі реалізаиії двофакторного експерименту на трьох рівнях варіювання. Послідовність проведення першого та наступних експериментів встановлено згідно з нумерованим порядком рандомізованої план-матричі планованого багатофакторного експерименту. Побудовано поверхні відгуків, їх двомірні перерізи пошкодження коренеплодів та кількості вибитих коренеплодів з трунту залежно від швидкості руху коренезбирального модуля та висоти коренеплодів. У межах збільшення висоти розташування головок коренеплодів над поверхнею трунту від 3 до 9 см пошкодження коренеплодів робочими органами двох типів виконання різального ножа та копіра обрізника головок коренеплодів збільшуються в середньому в 2,5...3 рази. Встановлено, що запропонована математична модель прочесу видалення залишків гички з головок коренеплодів адекватно описує отриманий експериментальний масив даних та відповідає досліджуваному процесу.
\end{abstract}

Ключові слова: гичка, коренеплоди, різання, двофакторний експеримент, ніж. 